\title{
Demand uncertainty and overcapacity in port infrastructures: the role of passengers and the effect of regulation
}

\section{Incertidumbre en la demanda y sobrecapacidad en la infraestructura portuaria: el papel de los pasajeros y el efecto de la regulación}

Núm. 4 (2015), pp. 21-39.

Hidalgo Gallego, Soraya ${ }^{{ }^{*}}$ Núñez-Sánchez, Ramón ${ }^{{ }_{2}}$ Coto-Millán, Pablo*3

JEL Clasif: R41, R42, R48

DOI: $10.5944 /$ reppp.4.2015.13151

\footnotetext{
*1 Soraya Hidalgo Gallego. Departamento de Economía. Universidad de Cantabria. Avda Los Castros, s/n. 39005 Santander (Spain). Tel: +34942200868. E-mail: hidalgos@unican.es

*2 Ramón Núñez Sánchez. Departamento de Economía. Universidad de Cantabria. Avda Los Castros, s/n. 39005 Santander (Spain). Tel: +34942206728. Web: http://personales.unican.es/nunezr. E-mail: nunezr@unican.es

*3 Pablo Coto Millán. Catedrático de Universidad de Fundamentos del Análisis Económico. Departamento de Economía. Universidad de Cantabria. Avda Los Castros, s/n. 39005 Santander (Spain). Tel: +3494220160o. E-mail: cotop@unican.es
} 
Demand uncertainty and overcapacity in port infrastructures:

the role of passengers and the effect of regulation

\begin{abstract}
This paper tries to assess the possible existence of excess of capacity for the Spanish port infrastructures. In order to do this, we estimate a cost function system considering the existence of demand uncertainty of cargo and passengers for port authorities. We find that, in order to fulfil the regularity conditions of the cost function system, we have to specify both demands as uncertain. The results show the importance of passenger variability in terms of demand of variable inputs and the use of quasi-fixed input. We also demonstrate the excess of capacity from the calculation of the shadow price of the quasi-fixed input after controlling demand uncertainty. Finally, some factors as the size of the port authorities' hinterland, the relative specialization in containerised general cargo or passengers, the size of ports, the profitability rate or port regulation are considered as determinants of this excess of capacity.
\end{abstract}

Key Words: ports; uncertainty of demand; cost function; overcapacity

\title{
Resumen
}

Se estudia la posible existencia de exceso de capacidad en las infraestructuras portuarias españolas. Para ello se estima un sistema de costes para las autoridades portuarias españolas en el que se incluye la incertidumbre en la demanda tanto para el tráfico de mercancía como para el de pasajeros. Se ha encontrado que para que sistema de costes cumpla todas las condiciones de regularidad es necesario incluir en la especificación la incertidumbre. Los resultados muestran la importancia de la variabilidad de pasajeros dado su efecto en las demandas de los factores productivos y en el uso del input quasi-fijo. También se demuestra la existencia de sobrecapacidad a partir del cálculo del precio sombra del input quasi-fijo una vez controlada la incertidumbre de la demanda. Finalmente, algunos factores tales como el tamaño del hinterland en el que la autoridad portuaria está localizada, la especialización relativa de la autoridad portuaria en los tráficos de contenedores y pasajeros, el tamaño de los puertos o su rentabilidad han sido considerados como posibles determinantes de este exceso de capacidad.

Palabras Clave: puertos; incertidumbre en la demanda; función de costes; sobrecapacidad 


\section{Introduction}

The Spanish port system has been the subject of significant regulatory changes during the last twenty five years. In this period, different public reforms have been carried out changing the way in which Spanish ports operate. Castillo-Manzano, López-Valpuesta and Pérez (2008), Núñez-Sánchez and Coto-Millán (2012) or Rodríguez-Álvarez and Tovar (2012) analyze the effects of port sector reforms in Spain showing that they had important effects on productivity and efficiency. These reforms have led the Spanish port authorities to operate according to the principles of a landlord port model: financial and operating autonomy, increased inter-port and intra-port competition and participation of the private sector in port activities. In this way, the port authority just provides the port infrastructure and regulates the use of port space. Port services are essentially provided by private sector operators under an authorisation or a concession regime (World Bank, 2007). However, Spanish port regulators have not allowed the existence of differences in prices among ports avoiding price-based competition. In this context, port authorities have had strong incentives to invest in capacity in order to attract more traffic of cargo and passengers. But this is not the only possible cause of port overcapacity. Haralambides (2002) identifies other factors which have guided port authorities to over-invest in capacity. Some of them are related with political issues, as the conception of ports as tools of regional development, technological issues, as capital indivisibilities (lumpy investments), economies of scale in port construction, increasing employment of containerships and larger vessels and planning issues, as the over-optimistic demand forecasts. Additionally, Luo, Liu and Gao (2012) consider that overcapacity could be a strategy for port authorities in order to gain credibility and effectiveness of preemptive measures (strategic issue). In this sense, the excess of capacity would not only attract more traffic, but also it would be a signal of reliability. This aspect is particularly relevant for those types of traffic under increased competitive pressure e.g. the case of containerised cargo or passenger traffic.

In this paper we focus on the possible existence of overcapacity in Spanish port authorities during the period 1986-2005 considering the effect of port demand variability on their costs, variable input demands and their quasi-fixed input. To achieve this aim, a system of equation formed by a short run variable cost function and input expenditures equations is estimated including proxies of demand variability for cargo and passengers. Other studies that have studied the existence of overcapacity in Spanish ports are Baños-Pino, Coto-Millán and Rodríguez-Álvarez (1999) and Rodríguez-Álvarez and Tovar (2012). Both papers demonstrate that ports authorities overuse their quasi-fixed inputs in the short- run, suggesting that adjustment in capacity investments are necessary in order to reach the long-run equilibrium. However, none of them have considered the inclusion of demand uncertainty on their specifications. Other two papers have considered demand variability in the production process of the cargo handling industry (Rodríguez-Álvarez, Tovar and Wall (2011), and Tovar and Wall (2012)). Nevertheless, both studies focus on the effect of demand uncertainty on cost efficiency, economies of scale and scope. Finally, Tovar and Wall (2014) analyse the impact of demand uncertain on port infrastructure costs. This paper is quite similar to ours but some significant differences exist, mainly methodological. Firstly, these authors focus in the cost of uncertainty whereas we analyse port overcapacity. Secondly, they do not include passengers' 
Demand uncertainty and overcapacity in port infrastructures:

the role of passengers and the effect of regulation

variability because it results non-significant when it is included in their regression. Nor they include the interactions between variability and inputs which allows to obtain the effect of uncertainty in inputs' demands. Third, variability is estimated in a different way in both papers. Tovar and Wall (2014) assume that cargo demand follows an autoregressive process of order 1 instead an autoregressive process of order 3 as we do. Moreover we approximate demand variability as predicted standard errors of this AR(3) process, however Tovar and Wall (2014) use predicted standard errors from a second regression where they regress the log of the squared estimated errors from the AR(1) process on port dummies and the lag of demand. Finally, they allows the coefficient associated with the quasi-fixed input to be positive. This fact is accepted by some authors arguing that reflects overcapacity, notwithstanding other authors consider this positive parameter as a misspecification of the model. The novelty in our study comes from that we focus on the infrastructure provision carried out by port authorities taking into account the interaction between demand uncertainty and port capacity, considered in our specification as a quasi-fixed input. In this way, we are able to observe whether the non-inclusion of demand uncertainty for cargo and passengers may cause biased results regarding the correct specification of the variable cost function. Additionally, we evaluate through a panel data model some observable factors which may partially cause the overcapacity of port authorities, taking into account both time-constant unobservable effects for every port authority and time effects.

The paper is structured as follows. First, in Section 2 we present the theoretical model of port authorities considering the existence of demand uncertainty. Section 3 presents the data used and some descriptive statistics of the different variables. Section 4 shows the econometric specification of the demand variability and next, the short-run variable cost system of equations. Section 5 shows the results of the estimations. Finally, Section 6 offers some conclusions and implications.

\section{Demand uncertainty and overcapacity on provision of port infrastructure and services}

As we have mentioned in the introduction, Spanish port authorities follow a landlord port model. They own the infrastructure, take decisions about the use of space, construction and financing of port infrastructure, as well as decisions about the provision and allocation of space to private companies which operate in the port. The port authority is responsible for the optimal operation of the facility, public or private, and security within the port. These infrastructures usually have an indivisible nature, this means that port infrastructure cannot adapt immediately to changes in demand, and therefore ports should have minimum dimensions and infrastructures to enable them to supply its potential demand. The problem arises in those periods when there are unexpected increases in demand. If ports do not have an excess capacity to enable them to face these increases, ships may suffer delays and congestion problems which in turn may lead to their clients to replace the port with a less congested one, generating reputation problems and loss of potential shippers. Then, ports do not want to deny clients due to potential excess demand. Thus, it is important that ports have sufficient capacity to keep the probability of excess demand below a desire level. This fact encourages overcapacity in ports. 
This can be modelled following Duncan (1990). Duncan develops a theoretical model which allows model the capacity service target of a firm. This model was empirically implemented by Anderson and Gaynor (1995) to hospital services.

The model assumes whether the output produced by a port authority $\left(y_{h t}\right)$ is function of a set of inputs $\left(x_{h t}\right)$ and demand that port faces $\left(d_{h t}\right)$ is a random variable with a conditional distribution on realizations in previous periods $\left(d_{h t-k}\right)$ which represents all relevant information than can be used to forecast the probability of demand exceeds capacity, we can obtain this probability which is equal to one minus the conditional distribution of the output on demand realizations in previous periods. As mentioned before, ports do not want to deny services to shippers, so they need to keep that probability under a given level $\alpha$, then:

$$
1-G\left(f\left(x_{h t}\right) \mid d_{h t-k}\right) \leq \alpha(1)
$$

Then, if $\left.G\left(f\left(x_{h t}\right)\right) d_{h t-k}\right)$ is invertible, we can replace $y_{h t}=f\left(x_{h t}\right)$ by $f\left(x_{h t}\right)=G^{-1}\left(1-\alpha \mid d_{h t-k}\right)$. This relation describes the production process of a port which produces so that demand exceeds capacity with probably $\alpha$, being the port authorities' production equal to their capacity target objective.

Therefore, the cost minimization problem is performed by adding the constraint that demand exceeds supply on average only a per cent of time to the standard cost minimization problem.

Based on the empirically implementation of Duncan (1990) model (Gaynor and Anderson, 1995) we consider two categories of inputs: quasi-fixed and variable inputs. Quasi-fixed input is the factor which cannot readily varied in response to unexpected realizations of demand $\left(S_{h t}\right)$; and variable inputs are factors which can be purchased in spot markets and can be perfectly adjusted once actual demand is realized $\left(x_{h t}\right)$. Variable inputs are chosen ex ante before demand is realized, but variable inputs can be varied in response to realizations of demand. So port authorities first choose variable and quasifixed inputs that minimize ex-ante cost with the constraint that demand can exceed supply on average only a per cent of time. From this minimization problem we are able to derivate ex-ante inputs demand, which depend on inputs prices, quasi-fixed input and capacity service target.

Additionally, Gaynor and Anderson (1995) suppose that the firm can adjust its variable inputs in the spot market once demand is realized. Then, in a second stage, the firm minimizes its ex-post cost, conditional on the ex-ante input demands, and subject to the production constraint. So ex-post cost can be expressed as

$$
V C=V C\left(y_{h t}, G^{-1}\left(1-\alpha \mid d_{h t-k}\right), w_{h t}, S_{h t}\right)
$$

Additionally, we can obtain the short run total cost function:

$$
T C\left(y_{h t}, w_{h t}, S_{h t}, G^{-1}\left(1-\alpha \mid d_{h t-k}\right)\right)=V C\left(y_{h t}, w_{h t}, S_{h t}, G^{-1}\left(1-\alpha \mid d_{h t-k}\right)\right)+r_{h t} S_{h t}
$$


Demand uncertainty and overcapacity in port infrastructures:

the role of passengers and the effect of regulation

where $T C$ is the short-run total cost function, $y$ is the vector for outputs, $w$ is the vector of input prices, $S$ is the quasi-fixed input, $G^{-1}\left(1-\alpha d_{h t-k}\right)$ is the target service capacity, $V C$ is the short run variable cost function and $r$ is the price of quasi-fixed input.

By minimizing the short-run total cost function we obtain the optimal quasi-fixed input level.

$$
\frac{\partial T C\left(y_{h t}, w_{h t}, S_{h t}, \sigma_{h t}\right)}{\partial S_{h t}}=\frac{\partial V C\left(y_{h t}, w_{h t}, S_{h t}, \sigma_{h t}\right)}{\partial S_{h t}}+r_{h t}=0
$$

which implies

$$
-\frac{\partial V C\left(y_{h t}, w_{h t}, S_{h t}, \sigma_{h t}\right)}{\partial S_{h t}}=r_{h t}
$$

A unit increase in a quasi-fixed input has two effects. First, it increases the quasi-fixed costs. But, second, it should lower short-run total variable costs. Equation (5) shows that a port authority should expand its quasi-fixed input as long as the savings on variable costs more than offset the increase in quasi-fixed costs. In this way, in the long-run equilibrium, the port authority is using an optimal amount of the quasi-fixed input so the variable cost savings just equal the unit price of the quasi-fixed input. In fact, the left-hand side of this equation (5) shows the saving of variable costs due to the increase of the quasi-fixed input, also known as the shadow price of the quasi-fixed input $\left(r_{s}\right)$. Meanwhile, the right-hand side is the unit price of the quasi-fixed input, which it should be evaluated in terms of the opportunity cost of the quasi-fixed input $(r)$. If both prices are equal the quasi-fixed input is optimally allocated. Thus, this equality allows us to test whether overcapacity occurs in Spanish ports or not by comparing the shadow price of storage area with its actual value (Baños-Pino, Coto-Millán and Rodríguez-Álvarez, 1999) following equation (6).

$$
q_{h t}=\frac{r_{h t}}{r_{s h t}}
$$

if $q_{h t}=1$ there is a long-run optimal allocation of the quasi-fixed input. When $q_{h t}>1$ the shadow price of the quasi-fixed input is lower than its opportunity cost so this input is being overused and thus overcapacity exists. Finally, if $q_{h t}<1$ the quasi-fixed input is being underused, so the port authority should expand its quasi-fixed input.

\section{Data}

The sample consists of 26 port authorities which manage 45 ports considered as being of general interest in Spain. For these ports annual data from 1986 until 2005 are available, being the complete panel data set of 520 observations ${ }^{1}$.

The data were gathered from the annual reports published by Puertos del Estado (several years, a and b) which provides homogeneous information about the performance of Spanish port authorities.

$1 \quad$ It is necessary to point out that the authorities from Almería and Motril are separated since 2005. However, in order to simplify the analysis, both authorities have been considered as a unit during the whole sample period. Additionally, the Port Authority of Sevilla was not included in the analysis as it is the only river port and, therefore, its cost structure responds to a quite different technology. 
The port activity is a multiproduct one, for this reason we have taken into account the following outputs: movements of liquid bulk $\left(y_{1}\right)$ and solid bulk $\left(y_{2}\right)$, containerised general cargo $\left(y_{3}\right)$, non-containerised general cargo $\left(y_{4}\right)$ and passengers $\left(y_{5}\right)$.

The input variables prices are: labour price $\left(w_{1}\right)$, variable capital price $\left(w_{2}\right)$ and intermediate consumption price $\left(w_{3}\right)$. We also consider the storage area of the port as a quasi-fixed input $(S)$. Labour price is defined as the ratio of annual labour expenses by total employees. Variable capital price has been approximated by multiplying a building index price of public works (obtained from the reports of Confederación Nacional de la Construcción, SEOPAN) by the sum of long-term interest rate and the depreciation rate the port's property and equipment. The depreciation rate is calculated as the annual depreciation expenditures of each port authority over the total assets. Finally, intermediate consumption price is defined as the ratio resulted by dividing intermediate consumption expense by intermediate consumptions measured in physical units.

We also include labour $\left(E_{1}\right)$, capital $\left(E_{2}\right)$ and intermediate consumptions $\left(E_{3}\right)$ expenses and the standard deviation of demand of total cargo and passengers traffic $\left(\sigma_{f}\right.$ and $\left.\sigma_{p}\right)$.

As we mentioned in Section 3, the market price of storage area has been included in our analysis to test whether overcapacity really occurs. This unit value, evaluated as the opportunity cost of the storage area, has been obtained from the public fees charged by port authorities to private port operators for using their public space, which Puertos del Estado annually publishes joint with the storage area of each port authority. In this way, given that Law 27/1992 indicates that these fees are equal to the six per cent of the land market value, we are able to determine the unit market value of the storage area.

\begin{tabular}{|c|c|c|c|c|c|c|c|}
\hline Variables & Description & Definition & Units & Mean & St. dev & $\operatorname{Max}$ & Min \\
\hline ve & Total variable costs & $\begin{array}{l}\text { The sum of labour, variable capital and intermediate } \\
\text { consumption expenses }\end{array}$ & Constant Euros 2001 & 17542922 & 12978007 & 67887624 & 1765523 \\
\hline $\mathrm{w}_{\mathrm{t}}$ & Labour price & The annual cost per employee & Constant Euros 2001 & 29240 & 9833 & 132921 & 2277 \\
\hline$w_{2}$ & Variable capital price & (Building price ${ }^{*}$ [real interest+depreciation)] ${ }^{*} 100$ & Percentage & 5.369 & 2.129 & 18.758 & 1.492 \\
\hline$w_{2}$ & Intermediate consumption price & $\begin{array}{l}\text { Intermediate consumption expense / intermediate } \\
\text { consumption }\end{array}$ & Constant Euros 2001 & 33.206 & 25.976 & 149.798 & 0.407 \\
\hline s & Quasi-fixed input & Stocking area & Squared-meters & 527205 & 608259 & 3106615 & 11354 \\
\hline $\mathrm{E}_{1}$ & Labour expenditure & Annual expenses in labour & Constant Euros 2001 & 6654308 & 4468384 & 24971912 & 976356 \\
\hline $\mathrm{E}_{2}$ & Capital expenditure & Annual expenses in variable capital & Constant Euros 2001 & 6687605 & 5328888 & 30204354 & 532770 \\
\hline$E_{2}$ & Intermediate consumption expenditure & Annual expenses in intermediate consumption & Constant Euros 2001 & 4201009 & 4046962 & 26283654 & 239554 \\
\hline$y_{2}$ & Liquid bulk & Annual liquid bulk traffic & Ton & 4714874 & 5707201 & 22772847 & 0.00 \\
\hline$y_{2}$ & Solid bulk & Annual solid bulk traffic & Ton & 2891856 & 3118134 & 19658167 & 5685 \\
\hline$y_{2}$ & Containerised general cargo & Annual containerised general cargo in tons & Ton & 1902290 & 4605169 & 35391361 & 0.00 \\
\hline$y_{*}$ & Non-containerised general cargo & Annual non-conta inerised general cargo in tons & Ton & 26828322 & 14427355 & 51735840 & 1179790 \\
\hline$y=$ & Passengers & Annual passengers & Passengers & 600722 & 1121689 & 5060090 & 0.00 \\
\hline GDP & GDP & Gross domestic product of port authority' hinterland & Constant Euros 2001 & 36463969 & 29410406 & 132767837 & 503726 \\
\hline contratio & Share of containerised on total cargo & Containerised cargo / total cargo & & 0.1155 & 0.1485 & 0.6462 & 0.00 \\
\hline prof & Profitability rate & (Incomes-expenses)/fixed assets & & 0.0289 & 0.0426 & 0.3661 & -0.2 \\
\hline pasimp & Passengers & Annual passengers/port surface & Passengers/squared meter & 4.034336 & 11.83272 & 79.28767 & 0 \\
\hline size & Cargo & Annual cargo traffic & Ton & $1.05 e+07$ & $1.01 \mathrm{e}+07$ & $6.36 \mathrm{e}+07$ & 326991 \\
\hline $\mathrm{r}$ & Quasi-fixed input price & $\begin{array}{l}\text { Obtained from public fees which port authorities charge by } \\
\text { the use of the port land }\end{array}$ & Constant Euros 2001 & 152.39 & 156.29 & 1705.67 & 7.79 \\
\hline
\end{tabular}

Table I: variables and simple descriptive statistics of the simple for the period I986-2005 


\section{Econometric Specification}

\subsection{Econometric specification for demand uncertainty}

Equation (2) shows that the variable cost is function of some observed variables: actual output, input prices and the quasi-fixed input which have been described in Section 2; and an unobserved one as the capacity which meets the desired turnaway probability.

As the target service capacity is not directly observable, we assume that greater demand uncertain needs greater reserve service capacity to meet this demand. Thus, the target service capacity is function of demand variability which can be approximated by the standard deviation of demand (Gaynor and Anderson, 1995; Rodríguez-Álvarez, 2011; Tovar and Wall, 2012 y 2014). So, in our study, an approximation of variability of demand for cargo and passengers, $\sigma_{f}$ and $\sigma_{p}$, are included in the model.

To estimate the standard errors of demand, since the demand ex-ante is an unobservable variable, we use the actual traffic of cargo and passengers as a proxy. Then we estimate a demand forecast equation following Gaynor and Anderson (1995). Considering that demand depends on past realizations, an autoregressive process of order three, $\mathrm{AR}(3)$, has been estimated for both cargo and passengers. We adopt the following strategy for the estimation: first, we regress demand of period $t$ on demand of periods $t-1, t-2$, $t-3$ for both traffics, including not only past information, but also port authority dummies and a time trend; once we have the estimations of the AR(3) processes, we proceed to estimate their corresponding standard errors.

Thus, the cost function becomes $V C=V C\left(y_{h t}, \sigma_{h t}, w_{h t}, S_{h t}\right) \quad$ (7)

where $V C$ is the variable cost, $y$ is the vector of inputs, $\sigma$ is the vector of demand uncertain variables, $w$ is the vector of input prices and $S$ is the input quasi-fixed.

\subsection{Econometric specification for the short-run variable cost system}

Once we have obtained the estimation of the demand variability variables, we proceed to specify the short-run variable cost system. For the estimation of the cost system, formed by the short run variable cost function and the input expenditure equations, a flexible functional form has been chosen, the multiproduct quadratic cost function. In this specification the variables, excepting those which are proxy of demand variability, are deviated from their means. This system of equations once the quadratic functional form has been applied is the following one:

$$
\begin{aligned}
& V C_{h t}=\beta_{0}+\sum_{r=1}^{m} \beta_{r}\left(y_{r h t}-\bar{y}_{r}\right)+\sum_{r=1}^{m} \sum_{s=1}^{m} \beta_{r s}\left(y_{r h t}-\bar{y}_{r}\right)\left(y_{s h t}-\bar{y}_{s}\right)+\sum_{j=1}^{n} \gamma_{j}\left(w_{j h t}-\bar{w}_{j}\right)+ \\
& +\sum_{j=1}^{n} \sum_{k=1}^{n} \gamma_{j k}\left(w_{j h t}-\bar{w}_{j}\right)\left(w_{k h t}-\bar{w}_{k}\right)+\sum_{r=1}^{m} \sum_{j=1}^{n} \rho_{r j}\left(y_{r h t}-\bar{y}_{r}\right)\left(w_{j h t}-\bar{w}_{j}\right)+\lambda_{S}\left(S_{h t}-\bar{S}\right)+ \\
& +\sum_{r=1}^{m} \lambda_{S r}\left(y_{r h t}-\bar{y}_{r}\right)\left(S_{h t}-\bar{S}\right)+\sum_{j=1}^{n} \lambda_{S j}\left(w_{j h t}-\bar{w}_{j}\right)\left(S_{h t}-\bar{S}\right)+\zeta_{f} \sigma_{f h t}+\zeta_{p} \sigma_{p h t}+ \\
& +\sum_{j=i}^{n} \zeta_{f j} \sigma_{f h t}\left(w_{j h t}-\bar{w}_{j}\right)+\zeta_{f_{S}} \sigma_{f h t}\left(S_{h t}-\bar{S}\right)+\sum_{j=i}^{n} \zeta_{p j} \sigma_{p h t}\left(w_{j h t}-\bar{w}_{j}\right)+\zeta_{p S} \sigma_{p h t}\left(S_{h t}-\bar{S}\right)+ \\
& +\sum_{a=1}^{A} D_{a} P A_{a}+\pi_{t} T+\varepsilon_{h t}
\end{aligned}
$$


The input expenditures equations can be obtained by applying the Shephard's Lemma to the cost function. Additionally, interactions of demand variability with input prices and quasi-fixed input are included in our model to allow variability gets not only into the variable cost but also in the input expenditures equations and therefore, we could test whether demand uncertainty affects input demands or not. Thus, the input expenditures equations included in the short-run variable cost function have been specified as follow:

$$
\begin{aligned}
& E_{j h t}=w_{j h t} \frac{\partial V C_{h t}}{\partial w_{j h t}}=w_{j h t} X_{j h t}^{*}=w_{j h t}\left[\gamma_{j}+2 \gamma_{j j}\left(w_{j h t}-\bar{w}_{j}\right)+\sum_{k=1}^{n} \gamma_{j k}\left(w_{k h t}-\bar{w}_{k}\right)+\right. \\
& \left.\sum_{r=1}^{m} \rho_{r j}\left(y_{r h t}-\bar{y}_{r}\right)+\lambda_{S j}\left(S_{h t}-\bar{S}\right)+\zeta_{f j} \sigma_{f h t}+\zeta_{p j} \sigma_{p h t}+v_{h t}\right]
\end{aligned}
$$

where $V C$ is the variable total cost, $y_{r}$ is the amount of output $r(r=1, \ldots, 5), w_{j}$ is the price of variable input $j(j=1, \ldots, 3), S$ is the quasi-fixed input, $\sigma_{f}$ is the proxy of demand variability of total cargo moved by the Spanish port authorities, $\sigma_{p}$ is the proxy of demand variability in the case of passengers, $E_{j}$ is the input $j$ expenditure, $T$ is a time trend representing neutral technical change, $h=1, \ldots, H$ relates to the $h$-th authority, $t$ relates to the time period and finally, to capture individual firm-specific effects, $P A$ represents port authorities dummies. Those variables which have a bar on the top correspond to the sample means.

\subsection{Econometric specification for the short-run variable cost system}

Finally, once overcapacity indices are obtained, we analyse some of the potential factors which cause overcapacity by equation (10). In this way we have considered variables related to the traffic composition. Usually, high percentages of containerised cargo are expected to increase the excess of capacity, given the competitive pressure of containerized traffic, with respect to solid or liquid bulk. The same applies to the case of passenger traffic, those port authorities with a greater intensity of passenger traffic present higher levels of overcapacity (strategic issues). Another possible explanatory factor could be related to the regulatory framework, given that Spanish port regulators follow the selffinancing principle. This rule tries to mitigate possible problems of moral hazard with individual port authorities (regulatory issue). In this sense, we have included the profitability rate of each port authority. Given the Spanish port finance system, we could expect that those port authorities with better performance may finance capacity expansions. On the other hand, we may consider that these port authorities achieve better results due to the fact that they are efficient, so they do not present higher levels of overcapacity. Therefore, the effect is not clear. Another factor related with overcapacity could be the economic importance of the port authority's hinterland, proxied by the GDP of the region in which the port is located. We expect that the larger the size of the hinterland, the lower the excess port capacity, due to the lower degree of spatial competition between ports (strategic issue). We also included the size of the port authority, measured by total cargo loaded/unloaded. Due to the existence of important capital indivisibilities, we consider that those port authorities with higher levels of traffic present lower overcapacity problems (technological issue). Finally, we have added temporal dummies in order to capture common temporal factors for all port authorities (political issues). For instance, those 
legal changes which affected the whole port system that we mentioned before (reforms in 1992 and 1997). Unfortunately, these variables presumably do not totally capture all of issues mentioned in section 1: political, technological, planning or strategic issues. However, the panel structure of our data can be used to obtain consistent estimators in the presence of omitted variables. The estimation of a fixed effects model assumes that unobserved effects are constant over time. Including dummies variables for port authorities and time, we are able to capture both time-constant unobserved effects and time effects.

$$
\begin{aligned}
& q_{h t}=\beta_{0}+\beta_{1} \text { contratio }_{h t}+\beta_{2} G D P_{h t}+\beta_{3} \text { prof }_{h t}+\beta_{4} \text { pasimp }_{h t}+\beta_{5} \text { size }_{h t}+ \\
& +\sum_{a=1}^{A} D_{a} P A_{a}+\sum_{d=1}^{D} G_{d} T D_{d}+\varepsilon_{h t}
\end{aligned}
$$

where $q$ are the overcapacity indices, contratio is the percentage of containerised cargo over total traffic, GDP is the gross domestic product of the hinterland where port authorities are located, prof is the profitability rate of port authorities, pasimp is the number of passengers on port surface, size is the total cargo traffic, $P A$ is an individual dummy variable for each port authority, $T D$ is a temporal dummy, $h=1, \ldots, H$ corresponds to the $h$-th authority and $t$ relates to the time period.

\section{Estimation and results}

The system of equations (8)-(9) has been estimated by seemingly unrelated regressions (SUR) model. In order to exploit the panel data structure, a fixed effects estimator has been applied for all specifications, considering the possible existence of time-constant unobserved effects.

Table 2 shows the results of the estimation using three different specifications for the system of equations with the aim of evaluate the robustness of the results: in specification 1 demand variability is not included; specification 2 includes the existence of demand uncertainty for cargo and passengers; and finally in specification 3 we just consider passengers' variability of demand, which we discuss below. The system of equations is formed by the short-run variable cost function and their three corresponding variable input expenditure equation.

\begin{tabular}{lcccccc}
\hline \multirow{2}{*}{ Variables } & \multicolumn{2}{c}{ Specification I } & \multicolumn{2}{c}{ Specification2 } & \multicolumn{2}{c}{ Specification3 } \\
\cline { 2 - 7 } & Coefficient & t-Statistic & Coefficient & t-Statistic & Coefficient & t-Statistic \\
\hline Constant & 19638778 & 5.435 & 10447635 & 1.918 & 9119287 & $1.84 \mathrm{I}$ \\
$\mathrm{w}_{1}$ & 201.52 & 49.128 & 142.43 & 2.858 & $102.1 \mathrm{I}$ & 3.884 \\
$\mathrm{w}_{2}$ & $\mathrm{I} 188425$ & 55.075 & $\mathrm{I} 13 \mathrm{I} 607$ & 3.389 & 773994.4 & 5.189 \\
$\mathrm{w}_{3}$ & 12064408 & 36.143 & 12706663 & 4.486 & 10472473 & 15.115 \\
\hline
\end{tabular}

Table 2: Estimation of the short run variable cost system using three different specifications. 


\begin{tabular}{|c|c|c|c|c|c|c|}
\hline \multirow{2}{*}{ Variables } & \multicolumn{2}{|c|}{ Specification I } & \multicolumn{2}{|c|}{ Specification2 } & \multicolumn{2}{|c|}{ Specification 3} \\
\hline & Coefficient & t-Statistic & Coefficient & t-Statistic & Coefficient & t-Statistic \\
\hline$y_{1}$ & 0.046 & 0.410 & 0.088 & 0.726 & 0.074 & 0.624 \\
\hline$y_{2}$ & 0.395 & 1.853 & 0.454 & 1.843 & 0.491 & 2.012 \\
\hline$y_{3}$ & 0.122 & 0.591 & 0.361 & 1.643 & 0.394 & 1.920 \\
\hline$y_{4}$ & 0.561 & 1.049 & 0.078 & 0.133 & 0.164 & 0.283 \\
\hline$y_{5}$ & 2.081 & 3.180 & 2.077 & 2.531 & 2.022 & 2.500 \\
\hline$S$ & 2.408 & 1.848 & -30.601 & -3.546 & -31.559 & -3.776 \\
\hline$w_{1} * w_{1}$ & -0.001 & -9.200 & -0.000 & -8.551 & -0.001 & -8.612 \\
\hline$w_{2} * w_{2}$ & -8466.79 & $-2.67 \mid$ & -8207.31 & -2.300 & -7557.8 I & -2.166 \\
\hline$w_{3} * w_{3}$ & -4550047 & -9.390 & $-4|378| 5$ & -8.003 & -4224733 & -8.161 \\
\hline$y_{1}^{*} y_{1}$ & 0.000 & -0.622 & 0.000 & -1.303 & 0.000 & -1.333 \\
\hline$y_{2}{ }^{*} y_{2}$ & 0.000 & -0.560 & 0.000 & 0.794 & 0.000 & 0.627 \\
\hline$y_{3} * y_{3}$ & 0.000 & -2.789 & 0.000 & -2.837 & 0.000 & -2.919 \\
\hline$y_{4}^{*} y_{4}$ & 0.000 & 1.389 & 0.000 & 2.048 & 0.000 & 1.998 \\
\hline$y_{5}^{*} y_{5}$ & 0.000 & 0.145 & 0.000 & 1.167 & 0.000 & $1.26 \mid$ \\
\hline$S * S$ & 0.000 & -0.211 & 0.000 & -0.791 & 0.000 & -0.627 \\
\hline$w_{1}^{*} w_{2}$ & 6.761 & 6.018 & 8.067 & 7.119 & 8.136 & 7.243 \\
\hline$w_{1}^{*} w_{3}$ & 28.041 & 1.218 & 28.606 & 1.231 & 22.109 & 0.951 \\
\hline$w_{2} * w_{3}$ & 314356.2 & 4.653 & 294835.5 & 4.077 & $28 \mid 494.8$ & 3.918 \\
\hline$y_{1}^{*} y_{2}$ & 0.000 & 5.601 & 0.000 & 5.212 & 0.000 & 5.324 \\
\hline$y_{1} * y_{3}$ & 0.000 & -1.394 & 0.000 & 0.428 & 0.000 & 0.439 \\
\hline$y_{1}{ }^{*} y_{4}$ & 0.000 & -0.733 & 0.000 & -1.549 & 0.000 & -1.604 \\
\hline$y_{1} * y_{5}$ & 0.000 & -1.427 & 0.000 & -1.786 & 0.000 & -1.660 \\
\hline$y_{2}^{*} y_{3}$ & 0.000 & -0.525 & 0.000 & -0.233 & 0.000 & -0.364 \\
\hline$y_{2}{ }^{*} y_{4}$ & 0.000 & -2.542 & 0.000 & -1.318 & 0.000 & -1.252 \\
\hline$y_{2}^{*} y_{5}$ & 0.000 & 2.984 & 0.000 & 2.892 & 0.000 & 2.857 \\
\hline$y_{3}{ }^{*} y_{4}$ & 0.000 & 3.337 & 0.000 & 2.850 & 0.000 & 2.788 \\
\hline$y_{3}{ }^{*} y_{5}$ & 0.000 & 2.597 & 0.000 & 1.431 & 0.000 & 1.367 \\
\hline$y_{4}^{*} y_{5}$ & 0.000 & -0.955 & 0.000 & -2.606 & 0.000 & -2.726 \\
\hline$w_{1}^{*} y_{1}$ & 0.000 & 2.558 & 0.000 & 3.029 & 0.000 & 2.825 \\
\hline$w_{1}^{*} y_{2}$ & 0.000 & 3.191 & 0.000 & 2.669 & 0.000 & 2.667 \\
\hline$w_{1}{ }^{*} y_{3}$ & 0.000 & -0.037 & 0.000 & 0.970 & 0.000 & 0.898 \\
\hline$w_{1}^{*} y_{4}$ & 0.000 & 1.219 & 0.000 & 0.526 & 0.000 & 0.472 \\
\hline$w_{1}{ }^{*} y_{5}$ & 0.000 & 2.493 & 0.000 & 2.088 & 0.000 & 2.085 \\
\hline$w_{2}{ }^{*} y_{1}$ & 0.037 & 9.600 & 0.039 & 9.034 & 0.037 & 8.999 \\
\hline
\end{tabular}

Table 2: Estimation of the short run variable cost system using three different specifications (cont.) 


\begin{tabular}{|c|c|c|c|c|c|c|}
\hline \multirow{2}{*}{ Variables } & \multicolumn{2}{|c|}{ Specification I } & \multicolumn{2}{|c|}{ Specification2 } & \multicolumn{2}{|c|}{ Specification 3} \\
\hline & Coefficient & t-Statistic & Coefficient & t-Statistic & Coefficient & t-Statistic \\
\hline$w_{2}^{*} y_{2}$ & 0.050 & 7.401 & 0.049 & 6.703 & 0.049 & 6.701 \\
\hline$w_{2}^{*} y_{3}$ & -0.006 & -0.822 & -0.001 & -0.187 & -0.003 & -0.353 \\
\hline$w_{2}^{*} y_{4}$ & 0.265 & 9.990 & 0.244 & 8.211 & $0.24 I$ & 8.156 \\
\hline$w_{2}^{*} y_{5}$ & 0.029 & 1.170 & 0.021 & 0.773 & 0.023 & 0.848 \\
\hline$w_{3}^{*} y_{1}$ & 0.2538 & $4.925 I$ & 0.2878 & 5.3237 & 0.2718 & 5.0674 \\
\hline$w_{3}^{*} y_{2}$ & 0.5027 & 5.7013 & 0.5573 & 6.2074 & 0.5679 & 6.3425 \\
\hline$w_{3}^{*} y_{3}$ & 0.9822 & 8.6022 & 1.0592 & 8.9493 & 1.0600 & 9.0717 \\
\hline$w_{3}^{*} y_{4}$ & -0.5324 & -1.7675 & -0.6907 & -2.1528 & -0.7139 & -2.2788 \\
\hline$w_{3}^{*} y_{5}$ & 1.7095 & 5.1400 & 1.9119 & 4.8382 & 1.8545 & 5.0708 \\
\hline$y_{1} * S$ & 0.0000 & 0.6420 & 0.0000 & 0.8116 & 0.0000 & 0.8784 \\
\hline$y_{2}{ }^{* S}$ & 0.0000 & -0.3342 & 0.0000 & -1.6195 & 0.0000 & -1.6096 \\
\hline$y_{3}{ }^{* S}$ & 0.0000 & I.705। & 0.0000 & 1.4205 & 0.0000 & 1.4400 \\
\hline$y_{4}{ }^{* S}$ & 0.0000 & -3.4990 & 0.0000 & -2.8740 & 0.0000 & -2.9274 \\
\hline$y_{5} * S$ & 0.0000 & -0.1713 & 0.0000 & -0.4685 & 0.0000 & -0.3759 \\
\hline$w_{1}^{*}$ S & 0.0001 & 9.8926 & 0.0001 & 10.7469 & 0.0001 & 10.7889 \\
\hline$w_{2} * S$ & 0.7215 & 13.0702 & 0.7678 & 12.7776 & 0.7686 & 12.8243 \\
\hline $\mathrm{w}_{3}{ }^{* S}$ & 5.9322 & 8.2092 & 5.8692 & 7.7626 & 5.8303 & 7.8056 \\
\hline $\mathrm{T}$ & -82874.10 & -2.5428 & -104891.70 & -2.5836 & -102416.40 & -2.5524 \\
\hline $\mathrm{T}^{2}$ & 10659.91 & 2.5745 & II 753.74 & 2.0020 & 11616.72 & 2.0049 \\
\hline$\sigma_{p}$ & & & 254903.20 & 4.5027 & 256314.20 & 4.6066 \\
\hline$\sigma_{p} * S$ & & & 0.8139 & 4.2152 & 0.7883 & 4.2336 \\
\hline$\sigma_{p}^{*} w_{1}$ & & & 1.8556 & 3.0210 & 2.0191 & 3.5186 \\
\hline$\sigma_{p}^{*} w_{2}$ & & & 8795.81 & 2.6778 & 8956.81 & 2.7516 \\
\hline$\sigma_{p}^{*} w_{3}$ & & & 16193.16 & 0.5491 & 32667.42 & 2.1532 \\
\hline$\sigma_{f}$ & & & -2043.98 & -0.4103 & & \\
\hline$\sigma_{f}^{*} S$ & & & -0.0048 & -0.6062 & & \\
\hline$\sigma_{f}^{*} w_{1}$ & & & -0.0915 & -0.8177 & & \\
\hline$\sigma_{f}^{*} w_{2}$ & & & -952.45 & -1.1345 & & \\
\hline$\sigma_{f}^{*} w_{3}$ & & & -4551.01 & -0.6862 & & \\
\hline
\end{tabular}

* Port authorities dummies have been omitted

Table 2: Estimation of the short run variable cost system using three different specifications (cont.) 


\begin{tabular}{|c|c|c|c|}
\hline & Specification I & Specification 2 & Specification 3 \\
\hline Observations & 520 & 442 & 442 \\
\hline $\mathrm{R}^{2}$ & 0.955 & 0.961 & 0.961 \\
\hline Adjusted $\mathrm{R}^{2}$ & 0.946 & 0.951 & 0.952 \\
\hline S.E. of regression & 3006937 & 2917533 & 289255 I \\
\hline $\begin{array}{l}\mathrm{R}^{2} \text { labour expenditure } \\
\text { equation }\end{array}$ & 0.567 & $0.64 I$ & $0.64 I$ \\
\hline $\begin{array}{l}\mathrm{R}^{2} \text { capital expenditure } \\
\text { equation }\end{array}$ & 0.771 & 0.772 & 0.772 \\
\hline $\begin{array}{l}\mathrm{R}^{2} \text { intermediate consumption } \\
\text { expenditure equation }\end{array}$ & 0.659 & 0.669 & 0.670 \\
\hline
\end{tabular}

Table 3: Descriptive statistics of the estimation of the short run variable cost system using three different specifications.

We observe that specification 1 satisfies some of the regularity conditions: the shortrun variable cost function is non-decreasing and quasi-concave in variable inputs prices, non-decreasing in outputs and homogeneous of degree one in input prices ${ }^{2}$. However, the coefficient related to the quasi-fixed area is positive and statistically different from zero. So according to this specification, one square meter increase of the storage area increases short-run variable costs. Some previous studies argue that this result indicates that firms are operating with considerable excess capacity (Viton, 1981). Nevertheless, we consider that the short-run variable cost function does not fulfill the regularity conditions and hence it does not capture the implicit technology. This fact shows that not taking into account demand uncertain can lead to misspecifications.

In specification 2 we include the existence of demand uncertainty for port authorities. Appendix A includes the estimates of the autoregressive processes $(A R(3))$ from which the demand variability variables have been obtained. The models perform well, satisfying the regularity conditions. In this way, first order coefficients related to the variable input prices are positive and statistically significant. For the case of outputs, parameters related to solid bulks, containerised cargo and passengers are positive and statistically different from zero. Given that the variables are deviated with respect to their means, output coefficients can be interpreted as the marginal cost of each category of traffic at the sample mean. Non-containerised general cargo and liquid bulk have positive coefficients but not different from zero. Additionally, we find evidence of the existence of technological progress since the coefficient associated to the trend is negative and significant. The coefficients related with demand variability of cargo and its interactions are all non-significant whereas the parameters associated to uncertainty for passenger traffic are significant, with only one exception $\left(\sigma_{p} w_{3}\right)$. In this sense, the coefficient related to the demand uncertainty of passengers $\left(\sigma_{p}\right)$ shows us that those ports which faces higher variability in their demand incurs in higher costs than those with lower uncertainty, for a given level of passengers. Moreover, regarding the interactions between the demand uncertainty passenger variable with input prices we conclude that port authorities increase the use of their labour and variable capital input in respond to demand uncertainty.

$2 \quad$ Unlike other functional forms for modeling the cost function the condition of homogeneity of degree one is imposed, in the case of the quadratic functional form we carry out a hypothesis testing procedure. In our case, the null hypothesis could not be rejected, so we conclude that short-run variable cost function is homogeneous of degree one. 
Regarding the storage area coefficient, it is negative and statistically significant at the sample mean. So one square meter increase of the storage area decreases short-run variable costs by $30.6 €$. Therefore, the inclusions of demand uncertainty variables in our system of equations achieve capture adequately the technology of port authorities.

Given that demand variability of cargo and its interactions are all non-significant, we calculate Specification 3, in which we just consider demand uncertainty of passengers. As we observe, results do not change substantially.

From deriving the variable cost with respect the quasi-fixed input, it is possible to calculate the shadow price of storage area $\left(r_{s}\right)$ for all observations in order to test the possibility of overcapacity, by comparing $r_{s}$ with the market price of the storage area $(r)$. Figure 1 shows the mean values of that ratio $(q)$ for each port authority. All authorities present levels of $q$ higher than one, excepting Bahía de Cádiz, so we can affirm that overcapacity occurs in most of the Spanish port authorities. The highest levels correspond to Ceuta and Melilla which are considered as strategic ports given that are located in Africa, followed by port authorities located in islands (Baleares, Las Palmas and Tenerife), Huelva and Alicante.

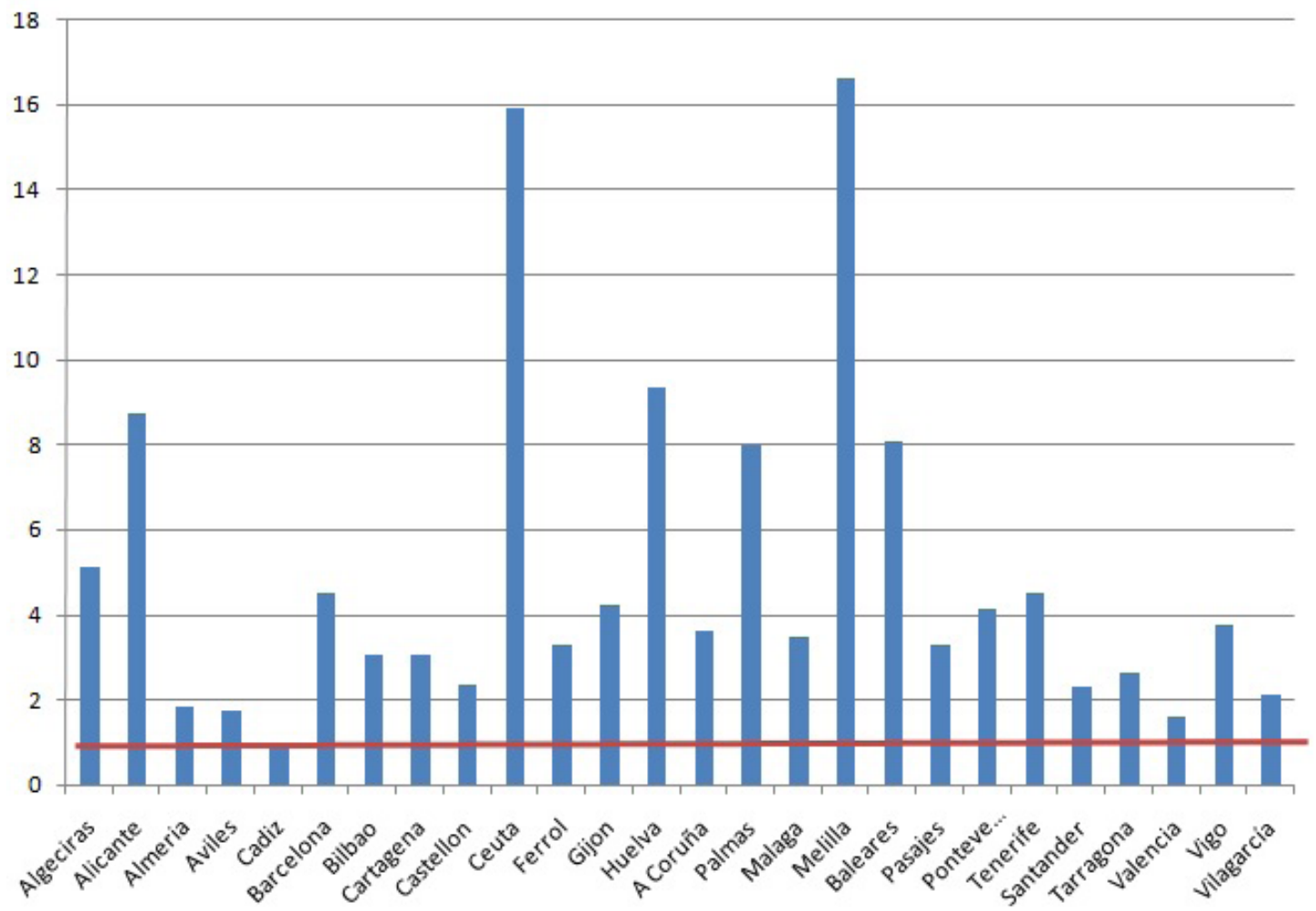

Figure I: Overcapacity indices (qh) for each port authority evaluated at their means

On the other hand, in Figure 2 we focus on the evolution of these indices for the whole Spanish port system. As we observe overcapacity has increased over the time distinguishing two different periods. During the first one, between 1986 until 1996, overcapacity increases, after the admission of Spain in the European Common Market and the first important reform of port authorities (Act 27/1992). The second period, starts in 1998 
one year after the 1997 reform (Act 62/1997), in which public regional governments were allowed appoint members of the port authority governing board. This new regulatory change increases the conception of ports as tools of regional development. Additionally, as we mentioned in the introduction, in this period port regulators have not allowed the existence of differences in prices among ports avoiding price-based competition ( $3^{\text {rd }}$ Transitory Regulation of Law 62/1997).Within this context, port authorities had strong incentives to invest in capacity rather than prices.

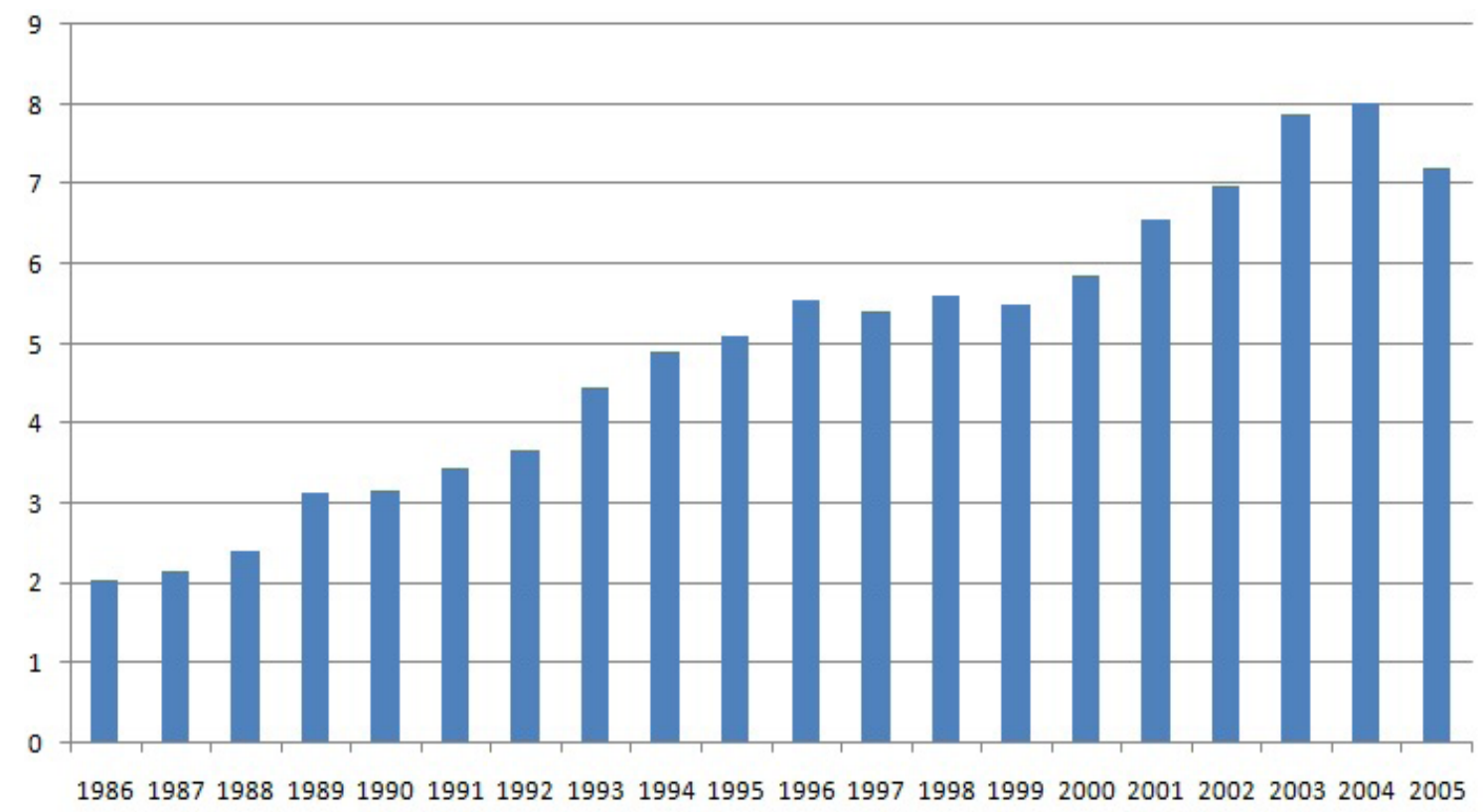

Figure 2: Evolution of overcapacity indices $\left(q_{t}\right)$ for the period 1986-2005

Therefore, although we have included demand variability in our short-run variable cost function, we observe that overcapacity in Spanish port system still remains. This fact could suggest that there would be other additional factors which could explain the overcapacity of the Spanish port authorities during this period. So we have evaluate these possible factors of overcapacity. In this way, we have first estimated equation (10) by OLS. Table 3 reports the results.

\begin{tabular}{lcccc}
\hline \multicolumn{1}{c}{ OLS } & \multicolumn{2}{c}{ 2SLS } \\
\hline \multicolumn{1}{c}{ Variables } & Coefficient & t-Statistic & Coefficient & t-Statistic \\
\hline const & $4.5 \mathrm{I} 5$ & 2.273 & 1.488 & 0.460 \\
contratio & 14.009 & 5.253 & 19.224 & 2.321 \\
GDP & $-8.68 \mathrm{E}-08$ & -4.553 & 0.000 & -2.936 \\
prof & 7.295 & 1.505 & 24.156 & 1.773 \\
pasimp & 0.283 & 7.797 & 0.370 & 2.070 \\
size & $-1.35 \mathrm{E}-07$ & -3.104 & 0.000 & -2.033 \\
\hline
\end{tabular}

Table 4: Determinants of overcapacity 


\begin{tabular}{|c|c|c|c|c|}
\hline \multirow[b]{2}{*}{ Variables } & \multicolumn{2}{|c|}{ OLS } & \multicolumn{2}{|c|}{ 2SLS } \\
\hline & Coefficient & t-Statistic & Coefficient & t-Statistic \\
\hline Alicante & 1.980 & 1.072 & 3.535 & 1.083 \\
\hline Almería-Motril & 0.152 & 0.093 & 1.850 & 0.838 \\
\hline Avilés & -4.729 & -2.281 & -1.786 & -0.534 \\
\hline Bahía de Cádiz & -2.847 & -1.585 & -0.931 & -0.315 \\
\hline Barcelona & 3.197 & 2.430 & 4.129 & 1.869 \\
\hline Bilbao & -0.201 & -0.134 & 2.760 & 0.960 \\
\hline Cartagena & -2.659 & -1.462 & -0.327 & -0.117 \\
\hline Castellón & -0.722 & -0.432 & 1.472 & 0.558 \\
\hline Ceuta & -8.017 & -3.091 & -9.857 & -1.072 \\
\hline $\begin{array}{l}\text { Ferrol-San } \\
\text { Cibrao }\end{array}$ & $-2.07 \mid$ & -1.089 & 0.504 & 0.173 \\
\hline Gijón & -0.838 & -0.439 & 2.292 & 0.705 \\
\hline Huelva & 7.695 & 4.997 & 10.635 & 4.170 \\
\hline A Coruña & -1.106 & -0.622 & 1.466 & 0.522 \\
\hline Las Palmas & -1.980 & -1.102 & -0.573 & -0.168 \\
\hline Málaga & 1.058 & 0.617 & 3.614 & 1.440 \\
\hline Melilla & 2.692 & 1.237 & 4.739 & 1.415 \\
\hline Baleares & -2.659 & -1.417 & -0.918 & $-0.34 I$ \\
\hline Pasajes & -1.698 & -0.867 & 1.563 & 0.480 \\
\hline $\begin{array}{l}\text { Marín y Ría de } \\
\text { Pontevedra }\end{array}$ & -3.200 & -1.611 & -1.159 & -0.362 \\
\hline $\begin{array}{l}\text { Santa Cruz de } \\
\text { Tenerife }\end{array}$ & -4.168 & -2.425 & -2.323 & -0.974 \\
\hline Santander & -4.744 & -2.235 & -1.661 & -0.486 \\
\hline Tarragona & 4.934 & 3.601 & 7.566 & 2.524 \\
\hline Valencia & -6.718 & -4.437 & -6.412 & -1.886 \\
\hline Vigo & $-5.96 I$ & -3.030 & -5.051 & -1.299 \\
\hline Vilagarcía & -3.459 & -1.654 & -0.070 & -0.020 \\
\hline D88 & -0.526 & -0.686 & -0.951 & -0.768 \\
\hline D89 & 0.463 & 0.597 & -0.028 & -0.028 \\
\hline D90 & 0.690 & 0.886 & 0.201 & 0.222 \\
\hline D9I & I. 184 & $\mathrm{I} .5 \mathrm{I} \mathrm{I}$ & $0.76 \mathrm{I}$ & 0.799 \\
\hline D92 & 1.520 & 1.928 & 1.038 & 0.966 \\
\hline D93 & 2.538 & 3.223 & 2.686 & 2.435 \\
\hline D94 & $2.94 I$ & 3.718 & 2.598 & 3.264 \\
\hline
\end{tabular}

Table 4: Determinants of overcapacity (cont.) 


\begin{tabular}{lcccc}
\hline \multicolumn{1}{c}{ Variables } & Coefficient & t-Statistic & Coefficient & t-Statistic \\
\hline D95 & 3.578 & 4.488 & 3.38 I & 4.366 \\
D96 & 3.999 & 4.970 & 3.785 & 4.398 \\
D97 & 3.908 & 4.771 & 3.857 & 5.087 \\
D98 & 4.164 & 4.991 & 3.960 & 4.654 \\
D99 & 4.076 & 4.762 & 3.722 & 4.458 \\
D00 & 4.705 & 5.336 & 4.308 & 4.626 \\
D0I & 5.596 & 6.147 & 5.155 & 5.244 \\
D02 & 6.279 & 6.692 & 5.828 & 5.085 \\
D03 & 7.399 & 7.632 & 6.940 & 5.034 \\
D04 & 7.309 & 7.639 & 6.903 & 5.142 \\
D05 & 6.849 & 7.023 & 6.445 & 3.853 \\
& & & & \\
Observations & & 520 & & 494 \\
R 2 & & 0.706 & & 0.701 \\
Adjusted R & & 0.676 & & 0.668 \\
S.E. of regression & & 3.141 & 3.229 \\
\hline
\end{tabular}

Table 4: Determinants of overcapacity (cont.)

The coefficient related to the share of containerised cargo on total traffic (contratio) and passenger traffic (pasimp) are positive and statistically significant, thus suggesting that the specialization on these types of traffic may lead the port authority to overinvest in capacity. On the other hand, the coefficient related to the hinterland size of the region where port authorities are located (GDP) has a negative and significant impact on excess of capacity. So, port authorities located in larger regions present lower excess capacity problems. The variable which controls the size of the port authority (size) also present a statistically positive coefficient. The existence of important fixed-capital indivisibilities or lumpy investments could explain these results. The estimation also indicates that the profitability rate of port authorities (prof) is not a significant variable. We also observe that both port authorities and time effects are highly significant. It is particularly interesting to analyse how coefficients related to time effects are not statistically different from 1986 until 1992, but in 1993 start to diverge. This result may suggest the effect of 1992 port reform on excess of capacity. We observe a similar effect after 2000, from which the coefficients increase in greater proportion than in previous years. Nevertheless, a potential pitfall of the results is that OLS do not consider possible problems of endogeneity in some explanatory. In order to solve this potential problem, we estimate (16) using Two-Stage Least Squares (TSLS) using as instruments lags of contratio, pasimp, size and prof. The results confirm the relationships explained before, but in this case the coefficient related to profitability rate of port authorities (prof) turn to be statistically significant, so there is a positive and significant correlation between excess of capacity 
Demand uncertainty and overcapacity in port infrastructures:

the role of passengers and the effect of regulation

and higher profit rates. Finally, temporal dummies bear out conclusions from figure 2, showing two different trends in overcapacity. Highest level of overcapacity with respect to the reference year, 1987, are those corresponding to the subsequent years to entry on force of the Law 62/1997. On the other hand, overcapacity seems to fall in the periods after Law 48/2003 came of force. This law is stricter with the objective of self-financing and operational costs coverage than the previous ones.

\section{Conclusions and implications}

This study analyses the overcapacity of the Spanish port authorities, taking into account the potential effect of the demand variability of cargo and passengers on the Spanish port authorities' productive process. Then, we have estimated jointly a short-run variable cost function with their corresponding input expenditure equations using three different specifications in order to check the robustness of the results. In the first specification, demand uncertainty has not been included in the model having found specification errors. Furthermore, although we have modelled cargo and passenger uncertainty demand, just demand variability of passengers and its interactions with the input prices and the quasi-fixed input are significant, which shows the importance of passengers in port studies. The results show that for a given level of output, those port authorities which face greater demand incurs in higher costs and use more variable inputs than those with less uncertain demand. On the other hand, we have demonstrated that overcapacity exists in port authorities and some determinants related to technological, strategic, political or regulatory issues, as specialization in certain traffics, port profitability or the size of their hinterlands affect to their excess of capacity. Additionally, we can distinguish two different trends in overcapacity indices for the whole Spanish port system, concurring one of them with the subsequent years to come into force Law 62/1997 when public regional governments have more competences in the port authorities' performance. It seems that an improvement in overcapacity levels occur after Law 48/2003.

\section{7. $\quad$ References}

Baños-Pino, J., Coto-Millán, P. \& Rodríguez-Álvarez, A. (1999). Allocative efficiency and overcapacity: An application. International Journal of Transport Economics, 26, 181-199.

Castillo-Manzano, J., López-Valpuesta, L. \& Pérez, J.J. (2008). Economic analysis of the Spanish port sector reform during the 1990s. Transportation Research Part A, 42, 1056-1063.

Duncan, G.D. (1990). The effect of probabilistic demands on the structure of cost functions. Journal of Risk Uncertainty, 3, 211-220.

Gaynor, M. \& Anderson, G.F. (1995). Uncertain demand, the structure of cost functions and the cost of empty hospital beds, Journal of Health Economics, 14, 291-317.

Haralambides, H.E. (2002). Competition, excess capacity and the pricing of port infrastructure. International Journal of Maritime Economics, 4, 323-347.

Revista de Evaluación de Programas y Políticas Públicas | Núm. 4 (2015), pp.21-39 
Luo, M., Liu, L. \& Gao, F. (2012). Post-entry container port capacity expansion. Transportation Research Part B, 46, 120-138.

Núñez-Sánchez, R. \& Coto-Millán, P. (2012). The impact of public reforms on the productivity of Spanish ports: A parametric distance function approach. Transport Policy, 24, 99-108.

Núñez-Sánchez, R., Jara-Díaz, S. \& Coto-Millán, P. (2011). Public regulation and passengers importance in port infrastructure costs. Transportation Research Part $A, 45,653-666$.

Puertos del Estado. Recuperado el 18 de septiembre de 2012 de http://www.puertos.es/ sistema_portuario/presentacion.html/

Puertos del Estado. (Several years a). Anuario estadístico. Madrid: Ministerio de Fomento.

Puertos del Estado. (Several years b). Informe de Gestión del Sistema Portuario de Titularidad Estatal. Madrid: Ministerio de Fomento.

Rodríguez-Álvarez, A., Tovar, B. \& Wall, A. (2011). The effect of demand uncertainty on Port Terminal costs. Journal of Transport Economics and Policy, 45, 303-328.

Rodríguez-Álvarez, A. \& Tovar, B. (2012). Have Spanish port sector reforms during the last two decades been successful? A cost frontier approach. Transport Policy, 24, 73-82.

Tovar, B. \& Wall, A. (2012). Economies of scale and scope in service firms with demand uncertainty: An application to a Spanish port. Maritime Economics and Logistics, $14,362-385$.

Tovar, B. \& Wall, A. (2014). The impact of demand uncertainty on port infrastructure costs: Useful information for regulators?. Transport Policy, 33, 176-183.

Viton P.A. (1981). A translog cost function for urban cost transit. The Journal of Industrial Economics, 29, 287-304.

World Bank. (2007). Port Reform Toolkit. WBI Development Studies. Recuperado de http://siteresources.worldbank.org/INTPRAL/ Resources/338897-1164990391106/oo_TOOLKIT_FM_Vol1.pdf 